\title{
ANTHROPOGENIC ACTIVITIES AND BIODIVERSITY THREATS
}

\section{Sadguru Prakash ${ }^{1}$ and Ashok Kumar Verma ${ }^{2 *}$}

${ }^{1}$ Department of Zoology, M. L. K. PG College, Balrampur (U.P.), India

${ }^{2}$ Department of Zoology, Govt. PG College Saidabad, Prayagraj (U.P.), India

${ }^{*}$ Corresponding author: akv.gdcz@gmail.com
Article Info:

Review Article

Received

25.01.2022

Reviewed

20.02.2022

Accepted

28.02.2022

\begin{abstract}
Biodiversity threats are one of the major concerns of today's intellectuals. These threats arise due to environmental problems that appear both due to natural processes as well as anthropogenic activities. Human activities that affect biodiversity are in fact critical environmental issues. These not only adversely affect humans but also other forms of life. Biodiversity is not an optional bonus in human affairs, but it is the foundation of human life and necessary for the existence and survival of humans and their sustainable development. So biodiversity conservation is not only a necessity to save the species but also helps in the conservation of habitats and such action is also likely to mitigate climate change. It is almost evident that habitat destruction and fragmentation, overexploitation, invasive species and climate change have the potential to create havoc in biodiversity loss. A major role in this regard is imparted by humans and their unsustainable and indiscriminate activities including overpopulation. This review article describes a correlation between anthropogenic activities and biodiversity threats i.e. the various types of anthropogenic activities that are responsible for biodiversity threats and loss.
\end{abstract}

Keywords: Anthropogenic activities, Biodiversity threats, Climate change, Environment.

Cite this article as: Prakash S. and Verma A. K. (2022). Anthropogenic activities and Biodiversity threats. International Journal of Biological Innovations. 4(1): 94-103. https://doi.org/10.46505/IJBI.2022.4110.

\section{INTRODUCTION}

Biodiversity includes assemblage of plants, animals and the micro-organisms; their genetic variability expressed in the varieties and populations; their habitats, ecosystems and natural areas, the mosaic of which gives richness to the natural environment. Biodiversity or biological resources provide food, clothing, housing, medicine and spiritual nourishment to human beings (Ashok, 2016). Humans depend on the living world for the resources and other benefits provided by biodiversity. But human activity is having adverse impacts on biodiversity through overpopulation, overexploitation, habitat destruction, pollution, introduction of invasive species, and climate change. The loss to biodiversity is mainly due to habitat destruction, over-harvesting, pollution and inappropriate as well as indiscriminate development and overexploitation of natural resources (Prakash, 2017; Kumar and Verma, 2017). 
The natural environment has been significantly affected by anthropogenic activities (Goudie, 2013). Between 1700s and 2000s, agricultural land area quintupled and the extent of natural vegetation was globally reduced by half (Scanlon et al., 2007; Pongratz et al., 2008). Furthermore many scientists argue that the recent rise in $\mathrm{CO}_{2}$ levels in the atmosphere is mainly due to anthropogenic activities (Ghosh and Brand, 2003; Prakash, 2021). Burning fossil fuels like coal and petroleum is the main cause of increased $\mathrm{CO}_{2}$. The global warming and climate change are imparting an insurmountable challenge for entire biota including humans. The climate change is mainly due to global warming and the main cause of global warming is enhanced greenhouse effect due to over anthropogenic activities (Verma, 2021). Non-systematic anthropogenic activities are the major culprits for these unfavourable changes. Biodiversity loss can result from a number of human activities, including habitat conversion and destruction; over-exploitation of species; disconnected patches of original vegetation; and air and water pollution.

Human activities and population growth threaten biodiversity in almost every corner of our planet. Local threats to species richness include land use changes, pollution, resource exploitation and invasive species. Conservation of biodiversity is a useful tool for managing natural resources and environment. Humanity impacts the planet's biodiversity in multiple ways, both deliberate and accidental. The biggest threat to biodiversity to date has been the way humans have reshaped natural habitats to make way for farmland, or to obtain natural resources, but as climate change worsens it will have a growing impact on ecosystems. The main direct cause of biodiversity loss is land use change (primarily for large-scale food production) which drives an estimated 30\% of biodiversity decline globally. Second is overexploitation (overfishing, overhunting and overharvesting) for things like food, medicines and timber which drives around 20\%. Climate change is the third most significant direct driver of biodiversity loss, which together with pollution accounts for $14 \%$. Invasive alien species account for $11 \%$ (TRS, 2021). Thus, the major threats to biodiversity are human activities and loss of habitat, overharvesting, deforestation, increasing wild trade, introduction of exotic species and climate change. In addition, the impact of anthropogenic activities on the environment can vary with time and from one region to another.

\section{HABITAT LOSS}

Growing demand for natural resources due to the increasing human population, more rapidly increasing per capita consumption and changing consumption patterns has meant that ever more natural habitat is being used for agriculture, mining, industrial infrastructure and urban areas resulting the habitat loss.

Habitat loss occurs when a particular area is converted from usable to unusable habitat. Industrial activities, agriculture, aquaculture, mining, deforestation, and water extraction are all central causes of habitat loss (Verma, 2017). This includes deforestation for wood for cooking food. Habitat loss from exploitation of resources, agricultural conversion, and urbanization is the largest factor contributing to the loss of biodiversity. Habitat fragmentation, the loss of large units of habitat, is also a serious threat to biodiversity. Human activities are causing a loss of biodiversity among animals and plants globally. This is a big challenge to save the natural habitat to conserve both the terrestrial and aquatic biodiversity (Arya, 2021; Chakraborty et al., 2021). The critical environmental issues provide an opportunity to focus for prioritizing research on the patterns, processes, and consequences of aquatic biodiversity. In turn, intimate knowledge of how human perturbations affect biodiversity ultimately provides clearer insight regarding the symptoms of changes in the sea caused by human activities (NAS, 1995). Tropical forests are under threat largely from conversion to other land-uses, while coral reefs are loss due to increasing levels of over exploitation and pollution. The rate of decline would represent 1000 to 10,000 times the expected rate of extinction without deforestation by humans. Some studies suggest that, globally, as many as one half of all mammal and bird species may become extinct within 200 to 300 years. Decreased biodiversity also interferes with 
essential ecological services such as pollination, maintenance of soil fertility, flood controls, water purification, assimilation of wastes and the cycling of carbon and other nutrients.

\section{OVERHARVESTING OR OVEREXPLOITATION}

Overharvesting or overexploitation means harvesting species from the wild at rates faster than natural populations can recover. Overharvesting drives loss of genetic diversity (Ryman et al., 1995). Overexploitation of natural resources is the serious threat to biodiversity i.e. many plant and animal species, but particularly to aquatic species. Overexploitation of species affects the loss of genetic diversity and the loss in the relative species abundance of both individual and /or groups of interacting species. The genetic diversity is buffer for biodiversity (Ashok, 2017). The population size gets reduced because of disturbances in age structure and sex composition. Humans are one of the components of biodiversity. There was harmonious cohabitation of humans and biodiversity on the primitive earth i.e. dynamic equilibrium existed between biodiversity and humans. Later on because of the following major changes human beings put heavy pressure on biodiversity: (1) Fast in growth of human population, (2) Increasing human needs, (3) Fast in domestication of animals, (4) Increase in human competence with technological advancement to exploit the biodiversity (GBS,1992), (5) overexploitation of natural resources. There are many examples of regulated commercial fisheries monitored by fisheries scientists that have nevertheless collapsed. The western Atlantic cod fishery is the most spectacular recent collapse. The causes of fishery collapse are both economic and political in nature (Dayton et al., 1995). Most fisheries are managed as a common (shared) resource even when the fishing territory lies within a country's territorial waters. The natural outcome of harvests of resources held in common is their overexploitation. While large fisheries are regulated to attempt to avoid this pressure, it still exists in the background. This overexploitation is exacerbated when access to the fishery is open and unregulated and when technology gives fishers the ability to overfish. In a few fisheries, the biological growth of the resource is less than the potential growth of the profits made from fishing if that time and money were invested elsewhere.

\section{DEFORESTATION}

The direct cost of deforestation is reflected in the loss of valuable plants and animal species. In recent decades, due to rapid human population increases, destruction of forest lands and improper cultivation practices (land use changes) have been seriously degrading native forest ecosystems and have caused undesirable effects in the watershed hydrologic conditions. Deforestation is also one of the important causes of biodiversity loss which is decisively influenced by the extension of agriculture. A very intensive cultivation and land use mismanagement are important factors in soil erosion and runoff generation. Human activities have always been accompanied by changes in land structure, destruction of natural resources and urban development (Khaleghi, 2017). Over the past century tropical forests have been suffering from exceptional rates of change as they are degraded or destroyed by human activities. Approximately half of the tropical forest that was present at the beginning of the twentieth century has already disappeared, with peak deforestation in the 1980s and 1990s (Wright, 2005).

Unfortunately, due to increasing population day by day; anomalous and incorrect use of natural resources and poor agricultural measurement practices, the rate of deforestation, and the use of marginal lands for cultivation purposes are disturbed. Decreasing soil organic matter is always a clear indication of soil degradation, and often is accompanied by reductions in water infiltration, fertility, and ability to retain fertilizers. Ploughing also exposes soils to wind and water erosion, resulting in large-scale pollution of freshwater resources. It is recognized that deforestation is the second major cause of increased $\mathrm{CO}_{2}$. While the amount of carbon released from fossil fuels increased dramatically from 6.15 gigatonnes (33.5 gigatonnes of $\mathrm{CO}_{2}$ ) in 1990 to 9.14 gigatonnes in 2010, land use contributed much less; its $\mathrm{CO}_{2}$ emission level decreased from 1.45 gigatonnes in 1990 to 0.87 gigatonnes in 2010 (Peters et al., 2011). Therefore, 
it is necessary to prevent such deplorable events through managing the environment and natural resources.

\section{INCREASING WILDLIFE TRADE}

Hunting is now a major cause of biotic population declines across the globe and in hunted forests, has caused declines of 58 and $83 \%$ in bird and mammal populations, respectively (Nijmegen, 2017). The illegal hunting of wildlife for internationally traded products, pets and as a food resource are directly responsible for the declines of emblematic species, such as elephant, rhinoceros, tiger, and so on. At its most extreme, over hunting can result in the extinction of largebodied animals in otherwise healthy intact habitat, driving changes in forest composition (William et al., 2018).

\section{INVASIVE SPECIES}

Invasive species are non-native species that have established outside their natural range, while introduced species have been established outside their natural range by human action into an ecosystem in which they did not evolve. Both invasive and introduced species can cause extinctions, alter abiotic environments, become pests, or introduce diseases (Bradshaw et al., 2009), particularly targeting species with a lower reproductive potential or those that are naive to competitors or predators (Purvis et al., 2000). Invasive species are major global change drivers and many studies have shown that they can alter biodiversity and ecosystem functioning ((Pejchar and Mooney, 2009; Vilà et al., 2011). Direct effects of invaders on ecosystem functioning could arise through alterations in disturbance regimes or nutrient levels. Indirect effects of biodiversity loss will only be important in comparison if invaders strongly reduce biodiversity and if biodiversity strongly affects functioning. Allan et al. (2015) showed that indirect effects of land-use intensification on ecosystem functioning, mediated by plant diversity, could be just as strong as the direct effects, while a study by Isbell et al. (2013) showed that indirect effects of diversity loss occurred but were much smaller than direct effects of nitrogen addition.

When an animal, plant, or microbe moves into a new area, it can affect the resident species in several different ways. New species can parasitize or predate upon residents, hybridize with them, compete with them for food, bring unfamiliar diseases, modify habitats, or disrupt important interactions. For example, the introduction of the brown snake on the island of Guam is thought to have caused the extinction of 12 of the 18 native birds (Wiles et al., 2003). These species can have devastating impacts on native biota, causing extinctions and affecting natural and cultivated ecosystems. Most exotic species introductions probably fail because of the low number of individuals introduced or poor adaptation to the ecosystem they enter. But sometimes these exotic species grows to well in that ecosystem and create several problem for native species of that ecosystem and also responsible for extension of some indigenous species (Prakash, 2017). These exotic species often undergo dramatic population increases in their new habitat and reset the ecological conditions in the new environment, threatening the species that exist there. For this reason, exotic species are also called invasive species. Exotic species can threaten other species through competition for resources, predation, or disease.

\section{POLLUTION}

The most harmful impact due to anthropogenic activities is pollution. Water quality is strongly influenced by anthropogenic activities pollutants that enter to the body of water as the result of human activities, such as domestic activities (households), urban activities, as well as industrial activities. Domestic activities (washing, cooking, and bathing) add some chemical residue to water and change its quality (Kalal et al., 2021). Cooking of food by using firewood may give out smoke in the air.

Agricultural activities may dump fertilizers and pesticides in the environment. Each activity, human or industrial, discharges some unwanted substances in the environment (Verma, 2018). The presence of unwanted substances in a concentration which can have an adverse effect on organisms and environment is called pollution. When something is added to the environment which is very harmful, poisonous or fatal to the animal, people surrounding it and other living things it is known as pollution. In 
simple term pollution is a contamination by a chemical or other pollutant that renders part of the environment unfit for intended or desired use.

Discharges of industrial, domestic and agricultural contaminants into water resources, combined to the elimination of riparian vegetation, erosion, terrestrial runoffs, irregular landfills, and so forth, contribute to the poor water quality and loss of biodiversity (Froehner et al., 2010). Industrial pollution has become a serious socio-economic problem in the heavily industrialized areas of the world and has become a global issue. Industrial pollution is caused by the discharge of a variety of pollutants in the form of gases, liquids and solids which affect the physical, chemical and biological conditions of the environment and are detrimental to human health, fauna, flora and soil properties (Dueck and Endendijk, 1987). Different types of industries are discharging different types of compounds in the environment. These compounds are varying in nature and cover wide range of effects on plants and animals both quantitatively and qualitatively. Industrial waste effluents have a disrupting and deleterious impact on the ecosystem and could reduce the number of species in a particular ecosystem and may lead to instability within plant communities. Air, soil and water pollution have far-reaching negative effects on biodiversity.

Pollution from burning fossil fuels such as oil, coal and gas can remain in the air as particle pollutants or fall to the ground as acid rain. Acid rain, which is primarily composed of sulfuric and nitric acid, causes acidification of lakes, streams and sensitive forest soils, and contributes to slower forest growth and tree damage at high elevations.

The concentration of pollutant in soil is highest in industrial area and contributing toxic impacts on biota of that region. Pollutant released from various sources has brought changes in the nature, structure and composition of the biological communities and could involve in the extinction of some important species. Various heavy metals ions, including $\mathrm{Pb}, \mathrm{Cd}, \mathrm{Ni}, \mathrm{Ti}, \mathrm{Cu}$, $\mathrm{Hg}, \mathrm{Cr}, \mathrm{Al}$ and $\mathrm{Zn}$ may enter plants by their root system. High levels of heavy metals were investigated in the soil samples from various areas of polluted cities (Khalid et al., 1996).

In addition, chemical pollutants such as pesticides and herbicides leach into soils and water bodies that in turn affect the physiology of aquatic animals including fishes (Praksh and Verma, 2014; Masih, 2021). Polluted streams result in the abandonment of natural spawning areas of fishes and ultimately in the loss of populations. Species' sensitivity to pollution is variable. However, many species are vulnerable to the indirect effects of pollution through the concentration of toxic chemicals in top predators of food chains and disruption of predator-prey interactions.

The production of reactive nitrogen by humans, mostly from manufacturing synthetic fertilizer to increase agricultural production, has changed ecological balances, both locally and in fardistant ecosystems. Anthropogenic production of reactive nitrogen leads to the release of nitrogen compounds into the atmosphere, which are subsequently deposited onto the biosphere. Addition of nutrient like nitrate and phosphate has a stimulating effect on phytoplankton growth and primary production, to a certain extent. The introduction of nutrient rich sewage change the algal community through eutrophication. Aerial deposition of nitrogen increases levels in ecosystems. Moreover, soluble nitrogen leaches from soils into groundwater, resulting in increased eutrophication of water bodies that stimulate excessive plant growth, algal blooms and the creation of anoxic (oxygen-free) zones in inshore marine areas.

\section{CLIMATE CHANGE}

Climate change is the change of climate over a longer period of time ranging from decades to centuries cause both by natural and human induced changes (Prakash and Srivastava, 2019. Verma, 2021). According to UNFCCC (United Nations Framework Convention on Climate Change) climate change is a change of climate which is attributed directly or indirectly to human activity that alters the composition of the global atmosphere and which is in addition to natural climate variability, observed over 
comparable time periods. Thus UNFCCC uses the term 'climate change' to mean only those changes that are brought about by human activities (Prakash, 2017). Climate change is also a day to day phenomenon but it should best be referred as climate variability. Climate change is expected to rival land-use change as the most important impact on tropical forest biodiversity.

Climate change, which is caused by a build-up of greenhouse gases such as carbon dioxide in the Earth's atmosphere, is a growing threat to biodiversity. As climate warms, species will migrate towards higher latitudes and altitudes in both hemisphere. The increase in the amount of $\mathrm{CO}_{2}$ in the air affects the physiological functioning of plant and species composition. The climate change influences the biodiversity, balanced ecosystem, environmental ethics and sustainable development (Verma, 2019, 2021). Carbon dioxide released from burning fossil fuels and biomass, deforestation, and agricultural practices contributes to greenhouse gases, which prevent heat from escaping the earth's surface. With the increase in temperature expected from increasing greenhouse gases, there will be higher levels of air pollution, greater variability in weather patterns, and changes in the distribution of vegetation in the landscape. Some species will not be able to adapt to these changes in the environment and will become extinct. However, it is expected that many plant and animal species will attempt to disperse to higher latitudes and altitudes as the temperature increases. Therefore, any barriers in the landscape, such as highways and urban areas that prevent movement to more hospitable environments, will result in loss of biodiversity.

Global warming will raise ocean levels due to melt water from glaciers and the greater volume of warmer water resulting the reduction in island size, which will have an effect on some species, and a number of islands as well as species will disappear entirely. Over the coming decades, human-induced climate change increasingly become another major factor in reducing biological/biodiversity (Prakash, 2014). These pressures on biodiversity are, to a large extent, driven by economic development and related demands including the increasing demand for biological resources.

Climate warming affects the phenology of species leading to potential mismatches between interacting species, for example, between pollinators and plants (Stenseth and Mysterud, 2002). Climate change also indirectly affects species by reducing the amount and availability of habitat, and by eliminating species that are essential to the species in question. Climate change alters the climate patterns and ecosystems in which species have evolved and on which they depend. By changing the temperature and rain patterns species have become accustomed to, climate change is changing the traditional ranges of species. This forces species to either move in order to find favourable conditions in which to live, or to adapt to their new climate. While some species may be able to keep up with the changes created by climate change, others will be unable to do so.

Climate change is likely to have a particularly large impact on tropical ectotherms, even taking into account behavioural thermoregulation, because they are relatively sensitive to temperature change and are living very close to their optimal temperature (Deutsch et al., 2008; Huey et al., 2009; Kearney et al., 2009). The decline in amphibian populations in Neotropical montane tropical forests, notably golden toads (Bufo periglenes), has been linked to changing climate (Pounds, 2001).

Coastal areas provide important ecosystem services for the development of various species including humans. However, diverse anthropogenic activities exacerbate of goods and services that support the communities along the coastline, impacting these areas and climate change (Poudel et al., 2017). Several problems especially rapid urbanization and the expansion social and cultural activities resulting in diverse dynamics of these ecosystems (Cai et al., 2016). It is, however, difficult to make a causal link between climate change and changes in species richness because of the many other variables involved.

India should be seriously concerned about the climate change as it is a very large developing 
country with significant rural population directly dependent on climate sensitive sectors like agriculture, forests and fisheries and natural resources (such as water, biodiversity, mangroves, coastal zones and grasslands) for their subsistence and livelihood.

\section{ECOSYSTEM FUNCTIONING}

Human activities have always been accompanied by changes in land structure, destruction of natural resources and urban development that caused the the loss of biodiversity (Yousefi et al., 2013; Kumar and Verma, 2016). If a species is lost from an ecosystem it is not just the species itself that is lost, but its interactions, and the ecological functions that result from these interactions, for example, seed dispersal. These interactions can be critical to the survival or functioning of another species or the ecosystem itself. Recently there was a focus on the relationship between network structure and ecosystem functioning, but there is an increasing realization that the loss of interactions can have pervasive effects on ecosystem structure and functioning and that species diversity, network structure and ecosystem functioning are closely linked (Memmott et al., 2007). More than one species may provide the same function in an ecosystem, providing ecological redundancy, for example, there may be many insects that pollinate a particular plant species (Walker, 1992). This may buffer the effects of the loss of one species, but how many species can we lose before we start to affect ecosystem functioning (Purvis and Hector, 2000). Loss of tropical forest at extraordinarily high rates is likely to overcome this buffer, and result in the loss of ecosystem functioning, with dramatic effects not only on tropical forests, but on ecosystem services that benefit humans, such as pollination.

\section{CONCLUSION}

Human activities are causing species to disappear at an alarming rate. The human population requires resources to survive and grow, and those resources are being removed unsustainably from the environment. The core threats to biodiversity are human population growth and unsustainable resource use. To date, the most significant causes of extinctions are habitat loss, deforestation, increasing wild trade, introduction of exotic species, overharvesting and climate change. Climate change due to human being is predicted to be a significant cause of extinctions of biodiversity in the coming century. Habitat loss occurs through deforestation, overharvesting, damming of rivers, and other anthropogenic activities. Overharvesting is a threat particularly to aquatic species. Exotic species have been the cause of a number of extinctions of indigenous species and are especially damaging to islands and lakes. Exotic species' introductions are increasing because of the increased mobility of human populations and growing global trade and transportation. Therefore, our ecological capital (forests, grasslands, wetlands, soils, biodiversity, and so on) must be protected. There is also a need for enforcement of regulations to control environmental pollution and loss of biodiversity. Public participation, NGO (non-governmental organization) and civic agencies of the government require a collective approach towards this solution. Continuous air monitoring for one or more pollutant is an absolute necessity for completing a diagnosis of pollution level in the surrounding i.e. air, water and soil environment.

\section{REFERENCES}

1. Allan E., Manning P., Alt F., Binkenstein J., Blaser S., Blüthgen N. and et al. (2015). Land use intensification alters ecosystem multifunctionality via loss of biodiversity and changes to functional composition. Ecology Letters. 18(8): 834-843. 10.1111/ele.12469.

2. Arya S. (2021). Freshwater Biodiversity and Conservation Challenges: A Review. International Journal of Biological Innovations. 3 (1): 74-78. https://doi.org/ 10.46505/IJBI.2021.3106.

3. Ashok K.V. (2016). Biodiversity: Its Different Levels and Values. International Journal on Environmental Sciences. 7(2): 143-145.

4. Ashok K.V. (2017). Genetic Diversity as Buffer in Biodiversity. Indian Journal of Biology. 4(1): 61-63. http://dx.doi.org/ 10.21088/ ijb.2394.1391.4117.9.

5. Bradshaw C.J.A., Sodhi N.S. and Brook B.W. (2009). Tropical turmoil: a biodiversity tragedy in progress. Front. Ecol. Environ. 7:7987. 10.1890/070193. 
6. Cai M., Liu Y., Chen K., Huang D. and Yang S. (2016). Quantitative analysis of anthropogenic influences on coastal water-A new perspective. Ecological indicators. 67: 673-683. https://doi.org/10.1016/ j.ecolind.2016.03.037.

7. Chakraborty B.K., Bhattacharjee S. and Muniya S. (2021). A Study on Aquatic Biodiversity of Shuthi-Shaiduli River of Bangladesh. International Journal of Biological Innovations. 3 (1): 58-67. https://doi.org/10.46505/IJBI.2021.3104.

8. Dayton P.K., Simon F., Thrush M., Tundi A. and Hofman R.J. (1995). Environmental Effects of Marine Fishing. Aquatic Conservation: Marine and Freshwater Ecosystems. 5 (3): 205-232. 10.1002/ aqc.3270050305.

9. Deutsch C.A., Tewksbury J. J., Huey R.B., Sheldon K.S., Ghalambor C.K., Haak D.C. and Martin P.R. (2008). Impacts of climate warming on terrestrial ectotherms across latitude. Proc. Natl Acad. Sci. USA. 105(18):6668-6672. 10.1073/ pnas. 0709472105.

10. Dueck T.A. and Endendijk G.J. (1987). Soil pollution and changes in vegetation. Chemosphere. 16:1021-1030.

11. Froehner S., Souza D.B., Machado K.S. and Rosa E.C. (2010). Tracking anthropogenic inputs in Barigui River, Brazil using biomarkers. Water Air Soil Poll. 201:33-41.

12. GBS (1992). Global Biodiversity Strategy: Guidelines for Action to Save, Study and Use Earth's Biotic Wealth sustainable and equitably. World Resources Institute (WRI), World Conservation Union (IUCN), United Nations Environmental programme (UNEP), IUCN, Gland, Switzerland.

13. Ghosh P. and Brand W.A. (2003). Stable isotope ratio mass spectrometry in global climate change research. Int. J. Mass Spectrom. 228:1-33. 10.1016/S13873806(03)00289-6

14. Goudie A. (2013). The human impact on the natural environment: past, present and future. 7th edn. A John Wiley \& Sons, Ltd., Publication. The Atrium, Southern Gate,
Chichester, West Sussex, PO19 8SQ, UK. 410p.

15. Huey R.B., Deutsch C.A., Tewksbury J.J., Vitt L.J., Hertz P.E., Perez H.J.A. and Garland T. (2009). Why tropical forest lizards are vulnerable to climate warming. Proc. $R$. Soc. B. 276(1664): 1939-1948. 10.1098/ rspb.2008.1957

16. Isbell F., Reich P.B., Tilman D., Hobbie S.E., Polasky S., Binder S. and Bren D. (2013). Nutrient enrichment, biodiversity loss, and consequent declines in ecosystem productivity. Proceedings of the National Academy of Sciences, USA. 110(29): 1191111916. 10.1073/pnas.1310880110.

17. Kalal V., Giri M.J., Baskar S. and Kuba R. (2021). Detection of Pollutants present in the surface water of Ayad River, Udaipur, Rajasthan. International Journal of Biological Innovations. 3 (1): 212-220. https://doi.org/ 10.46505/IJBI.2021.3123.

18. Kearney M., Shine R. and Porter W.P. (2009). The potential for behavioral thermoregulation to buffer 'cold-blooded' animals against climate warming. Proc. Natl Acad. Sci. USA. 106(10):3835-3840. 10.1073/ pnas.0808913106.

19. Khaleghi M.R. (2017). The influence of deforestation and anthropogenic activities on runoff generation. Journal of Forest Science. 63 (6): 245-253. https://doi.org/ 10.17221/130/2016-JFS.

20. Khalid F., Iqbal M.Z. and Qureshi M.S. (1996). Concentration of heavy metals determined in leaves and soil from various areas of Karachi, city. Environmental Sciences. 4: 213-219.

21. Kumar Ajay and Verma A.K. (2017). Biodiversity loss and its Ecological impact in India. International Journal on Biological Sciences. 8(2): 156-160.

22. Masih S.C. (2021). Impact of Monocrotophos pesticide on serum biochemical profile in freshwater fish, Cirrhinus mrigala (Hamilton, 1822). International Journal of Biological Innovations. 3(2):402-406. https://doi.org/ 10.46505/IJBI.2021.3222. 
23. Memmott J., Gibson R., Gigante C.L., Henson K., Huttel H.R., Lopezaraiza M.M. and Pearce S. (2007). The conservation of ecological interactions, pp 226-244. In Proc. Royal Entomological Society's 23rd Symp. Insect Conservation Biology (eds A. J.A. Stewart, T.R. New \& O.T. Lewis), Wallingford, UK: CABI Publishing.

24. NAS (1995). National Academies of Sciences, Engineering, and Medicine. Understanding Marine Biodiversity. Washington, DC: The National Academies Press. https://doi.org/ 10.17226/4923.

25. Nijmegen R.U. (2017). Hunting accounts for 83 and 58 percent declines in tropical mammal and bird populations. Science Daily. Retrieved on January 25, 2022 from www.sciencedaily.com/releases/2017/04/170 413141120.htm.

26. Pejchar L. and Mooney H.A. (2009). Invasive species, ecosystem services and human wellbeing. Trends in Ecology and Evolution. 24:497-504.

27. Peters G.P., Marland G., Le Quéré C., Boden T., Canadell J.G. and Raupach M.R. (2011). Rapid growth in CO2 emissions after the 2008-2009 global financial crisis. Nat. Clim. Change. 2:2-4.

28. Pongratz J., Reick C., Raddatz T. and Claussen M. (2008). A reconstruction of global agricultural areas and land cover for the last millennium. Global Biogeochemical Cycles 22(3):GB3018. https://doi.org/ 10.1029/2007GB003153.

29. Poudel S., Funakawa S. and Shinjo H. (2017). Household Perceptions about the Impacts of Climate Change on Food Security in the Mountainous Region of Nepal. Sustainability. 9(4):1-20. 10.3390/su9040641.

30. Pounds J.A. (2001). Climate and amphibian declines. Nature. 410:639-640. 10.1038/ 35070683.

31. Prakash S. (2014). Global warming and its impact on ecosystem, agriculture and human health. International Journal of Applied Research. 1(1):292-296.

32. Prakash S. (2017). Climate change and need of Biodiversity conservation: A review.
International Journal of Applied Research. 3(12):554-557.

33. Prakash S. (2021). Impact of Climate change on Aquatic Ecosystem and its Biodiversity: An overview. International Journal of Biological Innovations. 3(2):312-317. https://doi.org/10.46505/IJBI.2021.3210.

34. Prakash S. and Srivastava S. (2019). Impact of Climate Change on Biodiversity: An Overview. International Journal of Biological Innovations. 1(2): 60-65. https://doi.org/ 10.46505/IJBI.2019.1205.

35. Prakash S. and Verma A.K. (2014). Effect of Organophosphorus Pesticide (Chlorpyrifos) on the Haematology of Heteropneustes fossilis (Bloch). International Journal of Fauna and Biological Studies. 1(5): 95-98.

36. Purvis A. and Hector A. (2000). Getting the measure of biodiversity. Nature. 405: 212219. https://doi.org/10.1038/35012221.

37. Purvis A., Gittleman J.L., Cowlishaw G. and Mace G.M. (2000). Predicting extinction risk in declining species. Proc. R. Soc. Lond. B 267:1947-1952. 10.1098/rspb.2000.1234.

38. Ryman N., Utter F. and Laikre L. (1995). Protection of intraspecifc biodiversity of exploited fishes. Rev. Fish Biol. Fisheries. 5: 417-446.

39. Scanlon B.R., Jolly I., Sophocleous M. and Zhang Lu (2007). Global impacts of conversions from natural to agricultural ecosystems on water resources: Quantity versus quality. Water Resources Research. 43 (3): W03437. https://doi.org/ 10.1029/2006WR005486.

40. Stenseth N.C. and Mysterud A. (2002). Climate, changing phenology, and other life history and traits: nonlinearity and matchmismatch to the environment. Proc. Natl Acad. Sci. USA. 99(21): 13379-13381. https://doi.org/10.1073/pnas.212519399.

41. TRS (2021). The Royal Society of London. How do humans affect biodiversity? https://royalsociety.org/topics-policy/ projects/biodiversity/human-impact-onbiodiversity/.

42. Verma A.K. (2017). Multiple effects of Unsustainable Agriculture. International Journal on Agricultural Sciences. 8(1): 24-26. 
43. Verma Ashok Kumar (2018). Unsustainable Agriculture, Environmental Ethics and Ecological Balance. HortFlora Research Spectrum. 7 (3): 239-241.

44. Verma A.K. (2019). Sustainable Development and Environmental Ethics. International Journal on Environmental Sciences. 10 (1): 1-5.

45. Verma A.K. (2021). Influence of climate change on balanced ecosystem, biodiversity and sustainable development: An overview. International Journal of Biological Innovations. 3(2):331-337. https://doi.org/ 10.46505/IJBI.2021.3213.

46. Vilà M., Espinar J. L., Hejda M., Hulme P.E., Jarošík V., Maron J.L., Pergl J., Schaffner U., Sun Y. and Pyšek P. (2011). Ecological impacts of invasive alien plants: A meta-analysis of their effects on species, communities and ecosystems. Ecology Letters. 14(7): 702-708. 10.1111/j.14610248.2011.01628.x.
47. Walker B.H. (1992). Biodiversity and ecological redundancy. Conserv. Biol. 6(1):1823. 10.1046/j.1523-1739.1992.610018.x

48. Wiles G.J., Bart J., Beck R.E. and Aguon C.F. (2003). Impacts of the brown tree snake: patterns of decline and species persistence in Guam's avifauna. Conserv. Biol. 17:13501360.10.1046/j.1523-1739.2003.01526.x

49. William S.S., David P.E., Jukka M., Frank E.R. and Roman C.L. (2018). Combined impacts of deforestation and wildlife trade on tropical biodiversity are severely underestimated. Nature Communication. 9:4052. 10.1038/ s41467-018-06579-2.

50. Wright S. J. (2005). Tropical forests in a changing environment. Trends Ecol. Evol. 20: 553-560. 10.1016/j. tree.2005.07.009.

51. Yousefi Z., Amouei A.I. and Tahmasbizadeh M. (2013). Effect of chemical additives on availability of heavy metals ( $\mathrm{Pb}, \mathrm{Cd}$ and $\mathrm{Zn}$ ) of soil. Asian Journal of Chemistry. 25(12): 64966498 . https://doi.org/ $10.14233 /$ ajchem.2013.13880. 